\title{
QUALITY BY DESIGN APPROACH TO DEVELOP STABILITY INDICATING REVERSED-PHASE HIGH-PERFORMANCE LIQUID CHROMATOGRAPHY METHOD DEVELOPMENT FOR AMBROXOL
}

\author{
SUFIYAN AHMAD ${ }^{1 *}$, PRANIT KHABIYA ${ }^{1}$, TATIYA AU ${ }^{1}$, ABDURL RAHEMAN BAKHSHI ${ }^{2}$ \\ ${ }^{1}$ Department of Quality Assurance, Gangamai College of Pharmacy, Nagaon Bari, Maharashtra, India. ${ }^{2}$ Department of Pharmaceutical \\ Analysis, Royal College of Pharmaceutical Education and Research, Sayane Kh, Maharashtra, India. Email: sufimpharm@rediffmail.com
}

Received: 26 October 2021, Revised and Accepted: 23 October 2021

ABSTRACT

Objective: As per requisition of current regulatory requirements, simple, rapid and sensitive method by $3^{3}$ factorial quality by design approach was established and validated for Ambroxol (AMB) by reversed-phase high-performance liquid chromatography (RP-HPLC).

Methods: A simple RP-HPLC method has been developed and validated with different parameters such as linearity, precision, repeatability, limit of detection (LOD), limit of quantitation (LOQ), accuracy as per International Conference for Harmonisation guidelines (Q2R1). Statistical data analysis was done for data obtained from different aliquots Runs on Agilent Tech. Gradient System with Auto injector, ultraviolet (UV) diode-array detection and Gradient Detector.

Results: Equipped with Reverse Phase (Agilent) $\mathrm{C}_{18}$ column $(4.6 \mathrm{~mm} \times 100 \mathrm{~mm} ; 2.5 \mu \mathrm{m})$, a $20 \mu$ injection loop and UV730D Absorbance detector at $244 \mathrm{~nm}$ wave length and running chemstation 10.1 software and drugs along with degradants were separated via Methanol: (0.1\% orthophosphoric acid) Water (75:25) of pH 3 as mobile phase setting flow rate $0.7 \mathrm{ml} / \mathrm{min}$ at ambient temperature the retention time of AMB were found to be $4.85 \mathrm{~min}$. The industrialized method was found linear over the concentration range of $10-50 \mu \mathrm{g} / \mathrm{ml}$ for AMB while the LOD and LOQ of AMB was found to be $0.5174-0.2739 \mu \mathrm{g} / \mathrm{ml}$, analytical method that concluded.

Conclusion: There are no interfering peaks underperformed degradation conditions. Therefore, a sensitive, robust, accurate, and stability indicating method was developed with high degree of practical utility.

Keywords: Ambroxol, Quality by design, Reversed-phase high-performance liquid chromatography, Stability study, Method development, Validation.

(c) 2021 The Authors. Published by Innovare Academic Sciences Pvt Ltd. This is an open access article under the CC BY license (http://creativecommons.org/ licenses/by/4.0/) DOI: http://dx.doi.org/10.22159/ajpcr.2021v14i12.42939. Journal homepage: https://innovareacademics.in/journals/index.php/ajpcr

\section{INTRODUCTION}

The concept of "quality by design" (QbD) was defined as an approach that covers a better scientific understanding of critical process and product qualities, designing controls and tests based on the scientific limits of understanding throughout the development phase and by the knowledge obtained during the life-cycle of the product to work on a continuous improvement environment. QbD describes a pharmaceutical development approach referring to formulation design and development and manufacturing processes to maintain the prescribed product quality. Guidelines and mathematical models are used to ensure the establishment and use of the knowledge on the subject in an independent and integrated way [1-3].

Ambroxol hydrochloride (HCL) $[4,5]$ is a potent mucolytic and mucokinetic. Ambroxol (AMB) HCL is chemically Trans-4-([2-amino-3, 5-dibromobenzyl] amino)-cyclohexanol HCL (Fig. 1). AMB is indicated as "secretolytic therapy in bronchopulmonary diseases associated with abnormal mucus secretion and impaired mucus transport. It promotes mucus clearance, facilitates expectoration, and eases productive cough, allowing patients to breathe freely and deeply."

Moreover, the extensive literature inspection revealed that there is no reversed-phase high-performance liquid chromatography (RPHPLC) method obtainable for simultaneous estimation of AMB in the pharmaceutical dosage forms using experimental design approach QbD. A few analytical methods [6,7] have been reported in the literature for the determination of levofloxacin or AMB alone or combination with other drugs biological fluids, and pharmaceutical dosage forms. They include derivative spectrophotometric $[8,9]$ methods and other methods such as HPLC with ultraviolet (UV) detection, high-performance thinlayer chromatography $[10,11]$, and liquid chromatography with tandem mass spectrometry were also reported for the determination of AMB from human body fluids and pharmaceutical dosage form.

Regulatory authorities such as Food and Drug Administration and International Conference for Harmonisation (ICH) guidelines [12-14] are promoting and requesting the application of experimental design approach to understand chromatographic selectivity and support better method control, including method transfer. This prompted the investigators to adopt the experimental design in HPLC, and many papers were published related to this work [15-18]. The main impartial of our work is to develop an improved RP-HPLC method suitable for the routine quality control of AMB in a pharmaceutical industry and provide information on the sensitivity of chromatographic factors and their interaction effects on the separation characteristics. In our studies, no method has been reported for simultaneous estimation of the AMB drugs by using QbD based $3^{3}$ factorial designing.

\section{METHODS}

Chemicals and reagents

Reference standards of Naproxen HCL were obtained as gift sample from R.S.I.T.C Jalgaon, India. Pharmaceutical formulation was purchased after local market (Brand: Ambrolite tablet labeled claim AMB $30 \mathrm{mg}$ tablets India Ltd. 100 tab). The HPLC grade solvents used were of E-Merck (India) Ltd., Mumbai. HPLC grade Methanol and Ortho Phosphoric Acid (Merck, Mumbai, India) were used in the analysis. HPLC grade water was prepared using Millipore purification system. 


\section{Instruments}

The analysis of the drug was conceded out on Agilent Tech. Gradient System with Autoinjector, UV diode-array detection and Gradient Detector. Equipped with Reverse Phase (Agilent) $\mathrm{C}_{18}$ column (4.6 mm $\times 100 \mathrm{~mm} ; 2.5 \mu \mathrm{m}$ ), a $20 \mu \mathrm{l}$ injection loop and UV730D Absorbance detector and running chemstation 10.1 software.

\section{RP-HPLC optimised chromatographic condition using QbD}

Column $\mathrm{C}_{18} 100 \mathrm{~mm} \times 4.6 \mathrm{~mm}$ ); particle size packing $5 \mu \mathrm{m}$; detection wavelength $244 \mathrm{~nm}$; flow rate $0.7 \mathrm{ml} / \mathrm{min}$; temperature $26^{\circ} \mathrm{C}$ ambient; sample size $20 \mu \mathrm{l}$; mobile phase methanol: Water (Orthophosphoric acid $0.1 \% \mathrm{PH}$ 3) (75:25); run time $15 \mathrm{~min}$. The retention time (RT) for AMB was found at 3.822 min (Fig. 2).

Preparation of std. AMB solution: (Stock I)

An accurately weighed quantity, $10 \mathrm{mg}$ of $\mathrm{AMB}$ was dissolved in methanol in a $10 \mathrm{ml}$ volumetric flask and volume made up to $10.0 \mathrm{ml}$ to produce a solution of $1000 \mu \mathrm{g} / \mathrm{ml}$. From the freshly prepared standard stock solution $(1000 \mu \mathrm{g} / \mathrm{ml}), 0.1 \mathrm{ml}$ stock solution was pipetted out in $10 \mathrm{ml}$ of volumetric flask, and volume was made up to $10 \mathrm{ml}$ with mobile phase to get final concentration of $10 \mu \mathrm{g} / \mathrm{ml}$.

\section{Preparation of std. AMB solution: (Stock III)}

From the freshly prepared standard stock solution $(1000 \mu \mathrm{g} / \mathrm{ml}), 0.1 \mathrm{ml}$ stock solution was pipette out in $10 \mathrm{ml}$ of volumetric flask, and volume was made up to $10 \mathrm{ml}$ with mobile phase to get final concentration $10 \mu \mathrm{g} / \mathrm{ml}$.

\section{QbD approach to analysis}

The application of QbD in HPLC method growth commences with establishing analytical objectives based on sound science to ensure consistent method presentation characteristics are achieved. The use of QbD for an analytical way begins with defining the target analytical profile in which the pre-defined objectives for method performance must be appropriately validated and documented.

Thus the objective of this work was to perform experimental design by using Design Expert Software leading to develop simple, rapid, and sensitive method by QbD approach and validated as per ICH Guidelines (Q2R1) for Naproxen and Pantoprazole and its stability indicating method by RP-HPLC. Further statistical data analysis to be done along

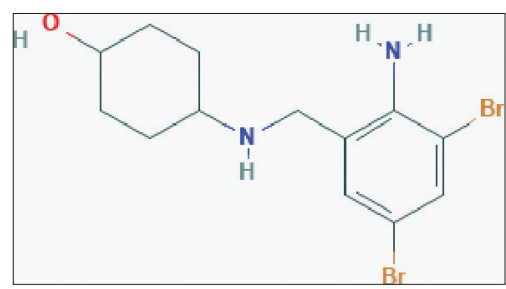

Fig. 1: Structure of ambroxol

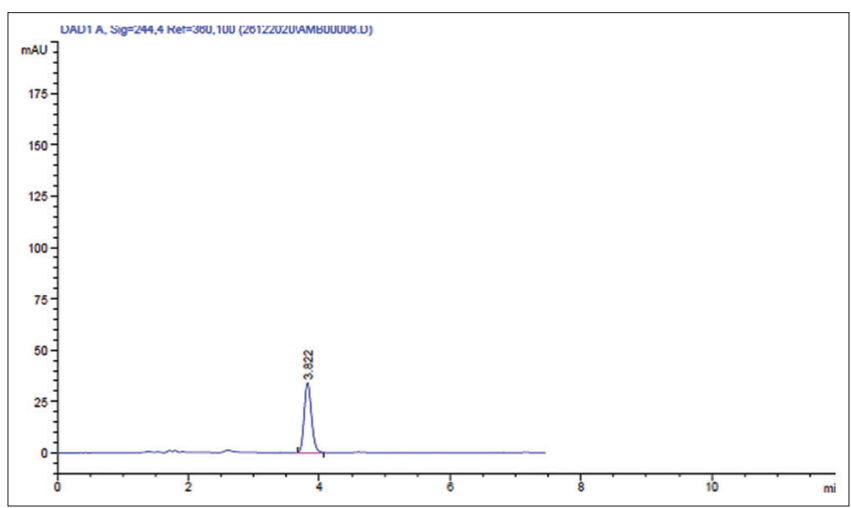

Fig. 2: Chromatogram of standard ambroxol at $244 \mathrm{~nm}$ with numerical and graphical optimization to develop Analytical Design Space.

\section{Method validation [19-21]}

Calibration curve

A calibration curve was constructed succeeding replicate $(n=6)$ analysis of five standards of $10,20,30,40$, and $50 \mu \mathrm{g} / \mathrm{ml}$ of AMB. The peak height ratio of drugs was calculated and plotted area under the curve (AUC) versus concentration after which least squares linear regression analysis of data was undertaken to establish the equation for the best fit line and the correlation coefficient $\left(\mathrm{R}^{2}\right)$ to authorize linearity. Samples were injected and peaks were recorded at $244 \mathrm{~nm}$ and the graph plotted as concentration of drug versus peak area as shown in (Table 1 and Fig. 3).

\section{Precision}

Intra-day (repeatability) precision was established following analysis of replicate samples $(n=6)$ at three concentrations indicative of low, medium, and tall levels within the linear range viz., 20, 30 and $40 \mu \mathrm{g} /$ $\mathrm{ml}$ of AMB. Analysis was performed over a small period of time on the same day. Inter-day precision or reproducibility was assessed at low, medium, and high concentration on three consecutive days and the percent relative standard deviation (\% RSD) was used to assess intra- and inter-day precision. An upper limit of $2 \%$ was used to confirm precision in our laboratory. Precision of an analytical method is usually expressed as standard deviation or RSD (Table 2).

\section{Accuracy}

Recovery studies were performed to validate the accuracy of developed method. To pre-analyzed tablet solution, a definite concentration of standard drug $(80 \%, 100 \%$, and $120 \%)$ was added and then its recovery was analyzed. Statistical validation of recovery studies shown in (Table 3).

\section{Specificity}

The specificity of an analytical method is defined as the ability of a method to ensure that the peak(s) of interest elute as distinct responses in the presence of excipients, impurities or degradation compounds

\section{Robustness}

To evaluate robustness few parameters were deliberately varied. The parameters include variation of flow rate, percentage of methanol as described in (Table 4).

\section{Study of system suitability parameters}

The system suitability is used to verify, whether the resolution and reproducibility of the chromatographic system are adequate for analysis to be done. The test was performed by collecting data from five replicate injections of standard solution as shown in (Table 5).

\section{Analytical method for tablet formulation}

Weigh 20 AMB tablets and calculated the average weight, accurately weigh and transfer the sample equivalent to $21 \mathrm{mg}$ AMB into $10 \mathrm{ml}$ volumetric flask. Add about $10 \mathrm{ml} \mathrm{MEOH}$ of diluent and sonicate to dissolve it completely and make volume up to the mark with diluent. Mix well and filter through $0.45 \mu \mathrm{m}$ filter. Further pipette $0.1 \mathrm{ml}$ of the above stock solution into a $10 \mathrm{ml}$ volumetric flask and dilute up to the

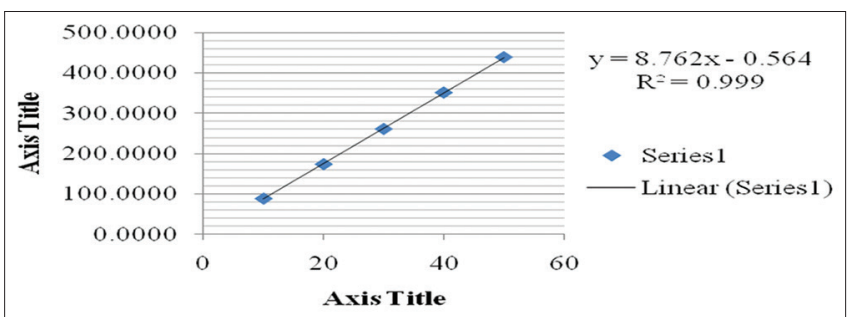

Fig. 3: Calibration curve of ambroxol 
Table 1: Linearity study AMB

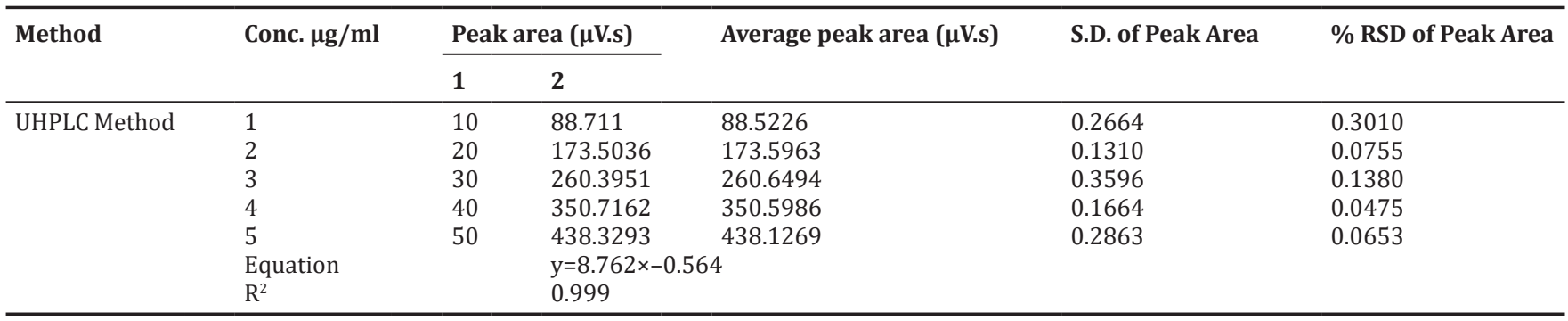

AMB: Ambroxol, UHPLC: Ultra-high performance liquid-chromatography

Table 2: Intraday and Inter day Precision studies on RP-HPLC method for AMB

\begin{tabular}{|c|c|c|c|c|c|c|}
\hline \multirow[t]{2}{*}{ Drug } & \multirow[t]{2}{*}{ Method } & \multirow[t]{2}{*}{ Conc. $(\mu \mathrm{g} / \mathrm{ml})$} & \multicolumn{2}{|c|}{ Interday Precision } & \multicolumn{2}{|c|}{ Intraday Precision } \\
\hline & & & Mean \pm SD & $\%$ Amt Found & Mean \pm SD & \%Amt Found \\
\hline \multirow[t]{2}{*}{ AMB } & HPLC & 10 & $462.24 \pm 1.43$ & 101.76 & $460.97 \pm 0.78$ & 101.50 \\
\hline & & 50 & $2427.94 \pm 1.48$ & 100.44 & $2429.47 \pm 1.56$ & 100.46 \\
\hline
\end{tabular}

AMB: Ambroxol, HPLC: High performance liquid-chromatography, *Mean of each 3 reading for reversed-phase high-performance liquid chromatography method

Table 3: Results of recovery studies AMB for RP-HPLC method

\begin{tabular}{|c|c|c|c|c|c|}
\hline Level (\%) & Amt. taken $(\mu \mathrm{g} / \mathrm{ml})$ & Amt. Added $(\mu \mathrm{g} / \mathrm{ml})$ & Absorbance Mean* \pm S.D. & Amt. recovered Mean $*_{ \pm}$S.D. & \%recovery Mean* \pm S.D. \\
\hline 80 & 10 & 8 & $18.00 \pm 0.065$ & $8.00 \pm 0.067$ & $100.04 \pm 0.82$ \\
\hline 100 & 10 & 10 & $20.01 \pm 0.043$ & $20.58 \pm 0.043$ & $100.19 \pm 0.42$ \\
\hline 120 & 10 & 12 & $22.00 \pm 0.022$ & $20.58 \pm 0.23$ & $100.01 \pm 0.18$ \\
\hline
\end{tabular}

*mean of each 3 reading, AMB: Ambroxol, RP-HPLC: Reversed-phase high-performance liquid chromatography

Table 4: Robustness evaluation of the HPLC method for AMB

\begin{tabular}{lll}
\hline Parameters & Conc. $(\boldsymbol{\mu g} / \mathbf{m l})$ & Amt. of detected (mean \pm SD) \\
\hline Chromatogram of flow change $0.6 \mathrm{ml}$ & 50 & $512.18 \pm 0.73$ \\
Chromatogram of flow change $0.8 \mathrm{ml}$ & 50 & $383.69 \pm 2.36$ \\
Chrom. of comp change wavelength change $243 \mathrm{~nm}$ & 50 & $418.1 \pm 0.66$ \\
Chrom. of comp change wavelength change $245 \mathrm{~nm}$ & 50 & $466.68 \pm 1.20$ \\
Chrom. of mobile phase change 74+26 ml & 50 & $439.4 \pm 1.20$ \\
Chrom. of mobile phase change 76+24 ml & 50 & $438.83 \pm 0.66$ \\
\hline
\end{tabular}

AMB: Ambroxol, HPLC: High-performance liquid chromatography, RSD: Relative standard deviation

Table 5: Repeatability studies on RP-HPLC method for AMB

\begin{tabular}{llll}
\hline $\begin{array}{l}\text { Conc. of AMB } \\
\text { (mg/ml) }\end{array}$ & Peak area & $\begin{array}{l}\text { Amount found } \\
\text { (mg) }\end{array}$ & $\begin{array}{l}\text { \% Amount } \\
\text { found }\end{array}$ \\
\hline 40 & 349.84027 & & \\
40 & 350.1496 & & \\
40 & 351.2675 & & 100.1435 \\
Mean & 350.4191 & 40.0574 & \\
SD & 0.7508 & & \\
\%RSD & 0.2143 & & \\
\hline
\end{tabular}

AMB: Ambroxol, RP-HPLC: Reversed-phase high-performance liquid

chromatography, RSD: Relative standard deviation

mark with diluents $(10 \mu \mathrm{g} / \mathrm{ml})$. The simple chromatogram of test AMB Shown in (Fig. 4) the amounts of AMB per tablet were calculated by extrapolating the value of area from the calibration curve. Analysis procedure was repeated five times with tablet formulation. Tablet Assay for \%Label claim for \% RSD Calculated, Result was shown in (Table 6).

\section{Forced degradation studies}

Forced degradation study was performed to evaluate the stability of the developed method using the stress conditions such as exposure of sample solution to acid, base, Hydrogen peroxides $\left(\mathrm{H}_{2} \mathrm{O}_{2}\right)$, and Neutral. Investigation was done for the degradation products in different conditions and are shown in (Table 7).
Table 6: Analysis of marketed formulation

\begin{tabular}{lllll}
\hline Method & Amt. Found & \% Label Claim & SD & \% RSD \\
\hline UHPLC & 50.14 & 99.89 & 0.06 & 0.06 \\
& 50.14 & 99.33 & 0.03 & 0.03 \\
\hline
\end{tabular}

UHPLC: Ultra-high performance liquid-chromatography, RSD: Relative standard deviation

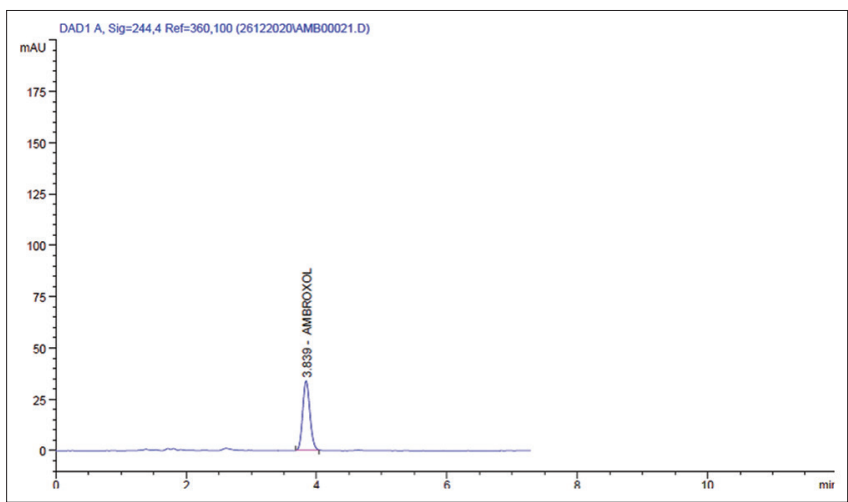

Fig. 4: Chromatogram for marketed formulation 

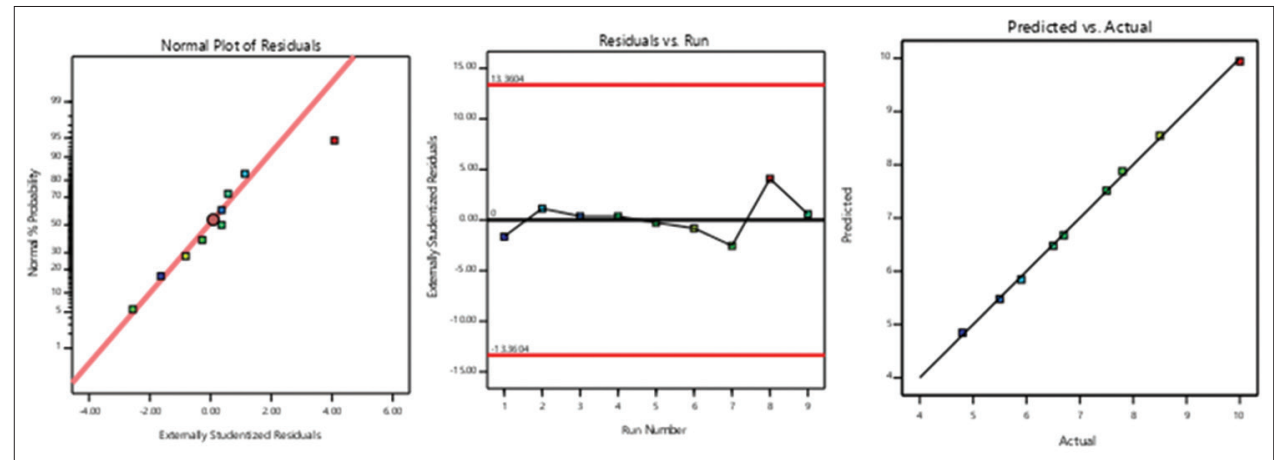

Fig. 5: Normal plot of residuals for retention time and plot of predicted versus actual data for retention time of cp
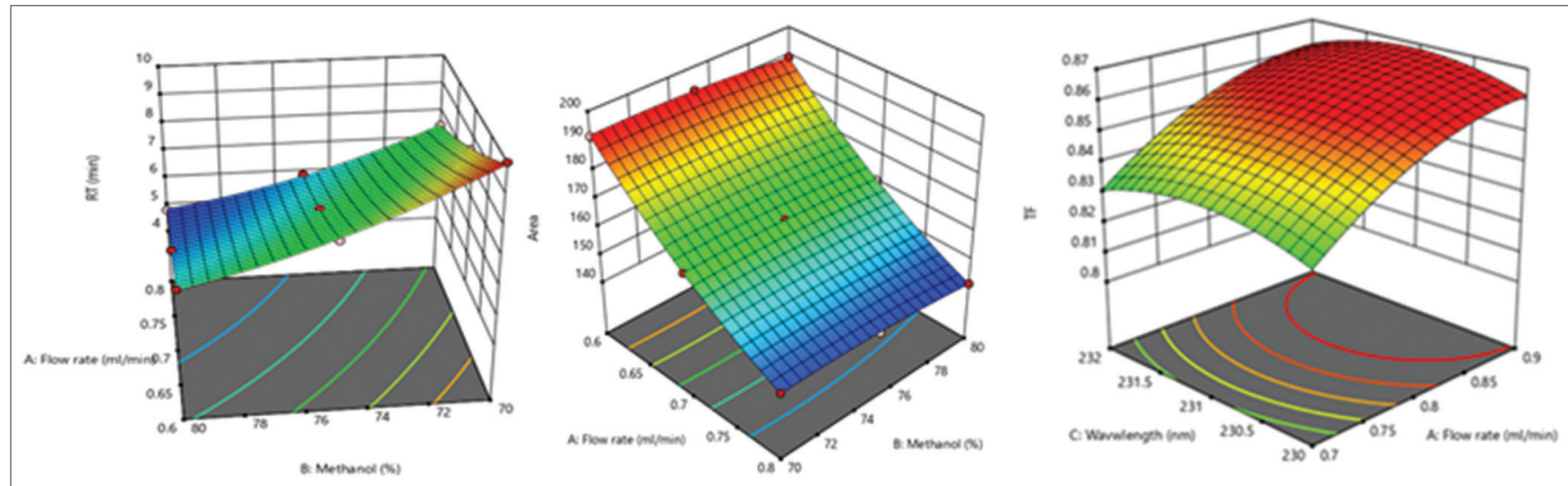

Fig. 6: Contour plot for flow rate, mobile phase composition and wave length

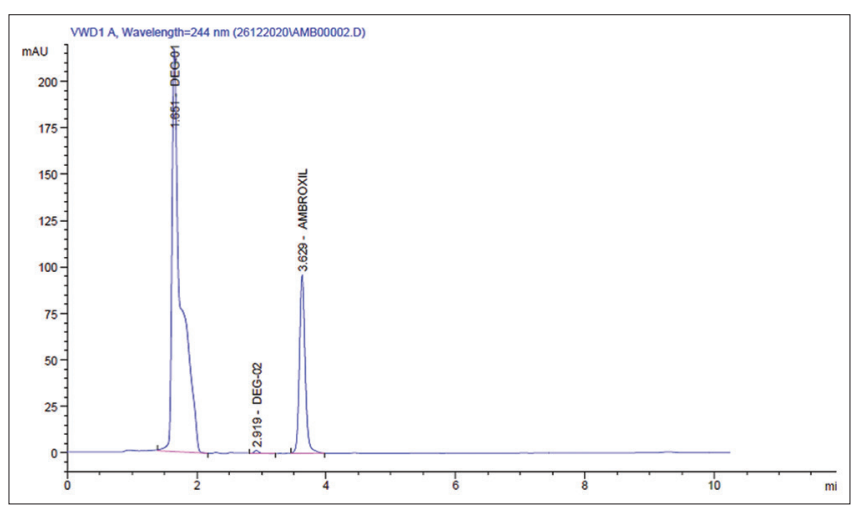

Fig. 7: Acidic degradation

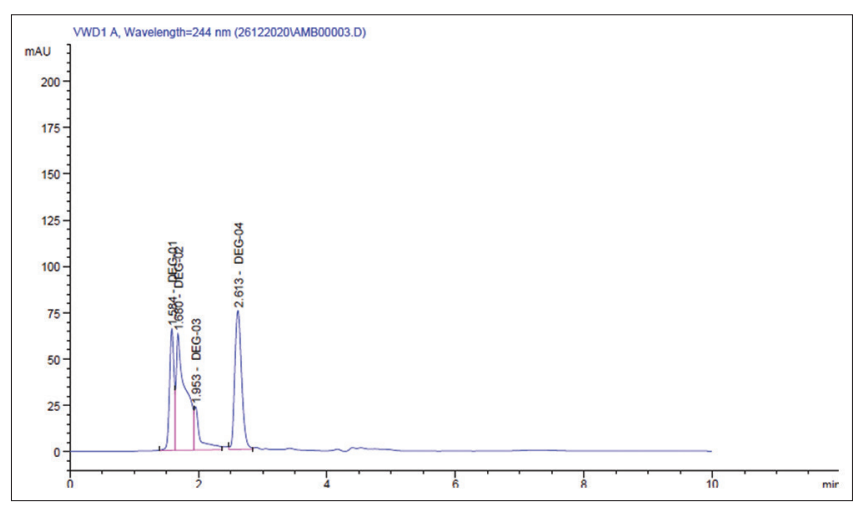

Fig. 8: Alkaline degradation

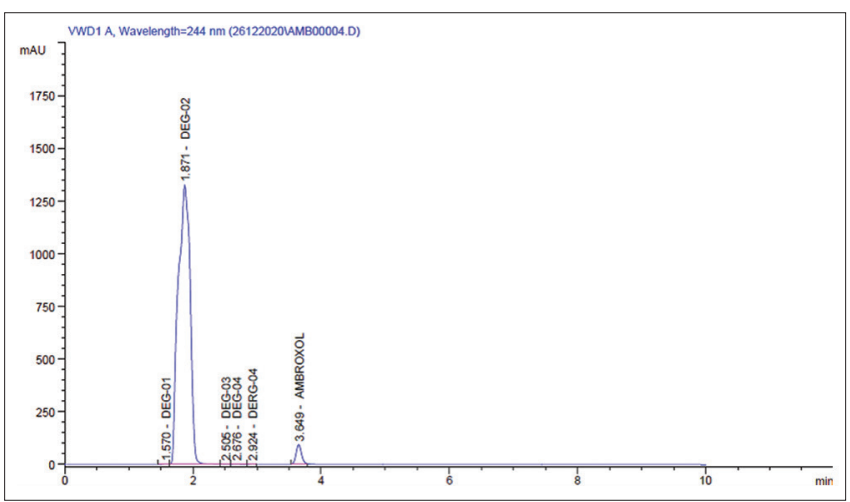

Fig. 9: Peroxide degradation

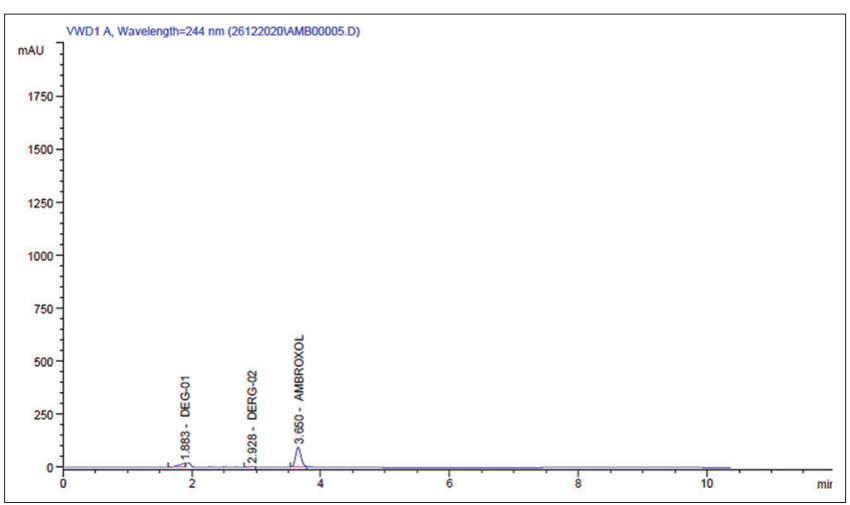

Fig. 10: Heat degradation 
Procedure for AMB degradation

\section{Acid hydrolysis}

The acid hydrolysis performed using $0.1 \mathrm{~N} \mathrm{HCl}$ at $70^{\circ} \mathrm{C}$ for $1^{\text {st }} \mathrm{h}$ for $\mathrm{AMB}$ to indicate degradation. The major degradation product for AMB was observed at relative RT (RRT) for $1^{\text {st }} \mathrm{h}$.

\section{Alkaline hydrolysis}

The alkaline hydrolysis condition was performed using $0.1 \mathrm{~N} \mathrm{NaOH}$ at $70^{\circ} \mathrm{C}$ for $1^{\text {st }} \mathrm{h}$ for $\mathrm{AMB}$. The major degradation product for AMB was observed at RRT for $1^{\text {st }} h$.

\section{Oxidation}

In the oxidation condition with $3 \% \mathrm{H}_{2} \mathrm{O}_{2}$ for $1^{\text {st }} \mathrm{h}$ AMB show oxidative stress degradation peak in the chromatogram.

Neutral

There was no major degradation observed for $\mathrm{AMB}$ and hence they were not sensitive to light at $70^{\circ} \mathrm{C}$ for $1^{\text {st }} \mathrm{h}$.

\section{RESULTS AND DISCUSSION}

Such analytical methods are, in fact, an indicator of a quality product and the robustness of that product for the duration on the lifecycle of that product. The main goal of any HPLC method is to separate and quantitate analyte(s) of interest from any impurity and/or excipients. Initially, it is important to establish the critical quality attributes of a system that may impact the quality of the analytical method. Development of Analytical RP-HPLC Method with Design Space and Control Strategy determination by optimization study all the computations for the current optimization study and statistical analysis were performed using Design Expert ${ }^{\circledR}$ software (Design Expert trial version). State-Ease Inc., Minneapolis, MN, USA).

Application of design of experiments (DOE-1) for method optimization DOE-1

Thus, 3 randomized response surface designs with a full fraction design were used with 17 trial runs to study the impact of three factors on the three key response variables. In this design three factors were evaluated, each at three levels and experimental trials were performed at all three possible combinations. The mobile phase composition $\left(\chi^{1}\right)$, Wavelength $\left(\chi^{2}\right)$, and flow rate $\left(\chi^{3}\right)$ were selected as independent variables and RT and Resolution were selected as dependent variables. The resulting data were fitted into Design Expert 10 Software and analyzed statistically using analysis of variance (ANOVA) and F-Test (Fig. 5) indicates the normal plot of residuals for RT with other chromatographic parameters. The data were also subjected to 3-D response surface methodology to determine the influence of flow rate, Wavelength, and mobile phase composition on dependent variables as shown in (Fig. 6). The probable trial runs using $3^{3}$ full fraction designs are as shown in (Table 4). Further ANOVA and F-test with variables are shown in (Tables 8-11). Moreover degradation peaks of API were shown in (Figs. 7-10) from acidic, alkaline, peroxide, and Heat.

Table 7: Forced degradation

\begin{tabular}{lll}
\hline Sample exposure condition & Total number of products with their Rt & AMB \\
\cline { 2 - 3 } & & Degradation remained (20 $\boldsymbol{\mu g} / \mathbf{m l})$ \\
\hline Acidic, $0.1 \mathrm{~N}, 1 \mathrm{~h}$ & $3(1.65,2.91,3.62)$ & 15.594 \\
Basic, $0.1 \mathrm{~N}, 1 \mathrm{~h}$ & $4(1.58,1.68,1.95,2.61)$ & 12.293 \\
Per oxide, $3 \%, 1 \mathrm{~h}$ & $6(1.57,1.87,2.50,2.67,2.92,3.64)$ & 7.134 \\
Heat, $70^{\circ} \mathrm{C}, 1 \mathrm{~h}$ & $3(1.88,2.92,3.65)$ & 18.20 \\
\hline
\end{tabular}

AMB: Ambroxol, RT: Retention time

Table 8: Probable trial runs using full fraction designs

\begin{tabular}{|c|c|c|c|c|c|c|c|}
\hline \multirow[t]{3}{*}{ Std } & \multirow[t]{3}{*}{ Run } & Factor 1 & \multirow{2}{*}{$\begin{array}{l}\text { Factor } 2 \\
\text { B: } \\
\text { Methanol }\end{array}$} & \multirow{2}{*}{$\begin{array}{l}\text { Factor } 3 \\
\begin{array}{l}\text { C: Wave } \\
\text { length }\end{array}\end{array}$} & \multirow{2}{*}{$\begin{array}{l}\text { Response } 1 \\
\text { RT }\end{array}$} & \multirow{2}{*}{$\begin{array}{l}\text { Response } 2 \\
\text { Area }\end{array}$} & \multirow{2}{*}{$\begin{array}{l}\text { Response } 3 \\
\text { TP }\end{array}$} \\
\hline & & $\begin{array}{l}\text { A: Flow } \\
\text { rate }\end{array}$ & & & & & \\
\hline & & $\mathrm{ml} / \mathrm{min}$ & $\%$ & $\mathrm{Nm}$ & $\min$ & AUC & Number \\
\hline 9 & 1 & 0.8 & 80 & 230 & 4.8 & 141.02 & 11675 \\
\hline 6 & 2 & 0.8 & 75 & 231 & 5.9 & 143.55 & 10892 \\
\hline 8 & 3 & 0.7 & 80 & 232 & 5.5 & 160.76 & 11693 \\
\hline 5 & 4 & 0.7 & 75 & 231 & 6.7 & 163.82 & 12789 \\
\hline 3 & 5 & 0.8 & 70 & 230 & 7.5 & 144.17 & 11458 \\
\hline 2 & 6 & 0.7 & 70 & 232 & 8.5 & 163.9 & 9810 \\
\hline 4 & 7 & 0.6 & 75 & 232 & 7.8 & 191.94 & 11373 \\
\hline 1 & 8 & 0.6 & 70 & 229.3 & 10 & 191.78 & 10645 \\
\hline 7 & 9 & 0.6 & 80 & 230 & 6.5 & 189.27 & 9777 \\
\hline
\end{tabular}

Table 9: ANOVA for reduced quadratic model (response 1: RT)

\begin{tabular}{llllll}
\hline Source & Sum of Squares & Df & Mean Square & F-value & p-value \\
\hline Model & 20.76 & 5 & 4.15 & 700.57 & 1046.53 \\
A-Flow rate & 6.20 & 1 & 6.20 & 2380.50 & $<0.0001$ \\
B-Methanol & 14.11 & 1 & 14.11 & 27.00 & $<0.0001$ \\
AB & 0.1600 & 1 & 0.1600 & 11.34 & 0.0138 \\
A $^{2}$ & 0.0672 & 1 & 0.0672 & 37.50 & 0.0435 \\
B $^{2}$ & 0.2222 & 1 & 0.2222 & & 0.0088 \\
Residual & 0.0178 & 3 & 0.0059 & \\
\hline
\end{tabular}

ANOVA: Analysis of variance, RT: Retention time 
Table 10: ANOVA for reduced quadratic model (response 3: Tp)

\begin{tabular}{|c|c|c|c|c|c|c|}
\hline Source & Sum of Squares & Df & Mean Square & F-value & p-value & \\
\hline Model & 3518.31 & 4 & 879.58 & 14284.03 & $<0.0001$ & Significant \\
\hline A-Flow rate & 3468.01 & 1 & 3468.01 & 56319.19 & $<0.0001$ & \\
\hline B-Methanol & 12.91 & 1 & 12.91 & 209.60 & 0.0001 & \\
\hline$A^{2}$ & 34.09 & 1 & 34.09 & 553.55 & $<0.0001$ & \\
\hline $\mathrm{B}^{2}$ & 3.31 & 1 & 3.31 & 53.77 & 0.0018 & \\
\hline Residual & 0.2463 & 4 & 0.0616 & & & \\
\hline Cor Total & 3518.56 & 8 & & & & \\
\hline
\end{tabular}

ANOVA: Analysis of variance

Table 11: Sequential Model Sum of Squares (Type I)

\begin{tabular}{lllll}
\hline Source & Sum of Squares & df & Mean Square & F-value \\
\hline Mean versus Total & $2.467 \mathrm{E}+05$ & 1 & $2.467 \mathrm{E}+05$ & \\
Linear versus Mean & 3480.92 & 2 & 1740.46 & 277.41 \\
2FI versus Linear & 0.1024 & 1 & 0.1024 & 0.0136 \\
Quadratic versus 2FI & 37.40 & 2 & 18.70 & 389.80 \\
Cubic versus Quadratic & 0.1026 & 2 & 0.0513 & 0.0001 \\
Residual & 0.0413 & 1 & 0.0413 & 0.0002 \\
Total & $2.503 \mathrm{E}+05$ & 9 & 27807.32 & 0.5360 \\
\hline
\end{tabular}

\section{CONCLUSION}

A simple, rapid, reliable, robust, and optimized reversed phase highperformance liquid chromatographic method for estimation of Naproxen and Pantoprazole was successfully developed and validated as per ICH guidelines. Percentage of mobile phase, flow rate, and wavelength was optimized by using $\mathrm{QbD}$ approach i.e. $3^{3}$ factorial design. There are no interfering peaks underperformed degradation conditions. Therefore, a sensitive, accurate, and stability-indicating method was developed with high degree of practical utility.

\section{ACKNOWLEDGMENT}

The authors are grateful thanks to the Management and Principal of Gangamai College of Pharmacy, Nagaon, Dhule, Maharashtra, for providing timely support for the research work.

\section{CONFLICTS OF INTEREST}

The authors declare no conflicts of interest.

\section{REFERENCES}

1. Raman NV, Reddy U. Analytical quality by design approach to test method development and validation in drug substance manufacturing. J Chem 2015;2015:435129.

2. Patel MN, Kothari CS. Multivariate approaches for simultaneous determination of avanafil and dapoxetine by UV chemometrics and HPLC-QbD in binary mixtures and pharmaceutical product. J AOAC Int 2016;99:649-63.

3. Tol T, Kadam N, Raotole N, Desai A, Samanta G. A simultaneous determination of related substances by high performance liquid chromatography in a drug product using quality by design approach. J Chromatogr A 2016;1432:26-38.

4. Indian Pharmacopoeia. Government of India, Ministry of Health and Family Welfare. Vol. 2. Ghaziabad: The Indian Pharmacopoeia Commission; 2010. p. 1272-3.

5. Heinanen M, Barbas C. Validation of an HPLC method for the quantification of ambroxol hydrochloride and benzoic acid in a syrup as pharmaceutical form stress test for stability evaluation. J Pharm Biomed Anal 2001;24:1005-10.

6. Indrayanto G, Handayani R. Quantitative determination of ambroxol hydrochloride in tablets. J Pharm Biomed Anal 1993;11:781-4.

7. Pérez-Ruiz T, Martínez-Lozano C, Sanz A, Teresa San Miguel M. Automatic extraction spectrophotometric method for the determination of ambroxol in pharmaceutical preparations. Talanta 1996;43:1029-34.

8. Agrawal OD, Shirkhedkar AA, Surana SJ. Simultaneous determination of levofloxacin hemihydrate and ambroxol hydrochloride in tablets by thin layer chromatography combined with densitometry. J Anal Chem 2010;65:418-22

9. Krupa M, Kothekara B, Balasundaramjayakar N. Quantitative determination of levofloxacin and ambroxol hydrochloride in pharmaceutical dosage form by reversed-phase high performance liquid chromatography. Eur J Anal Chem 2007;2:21-2.

10. Zar JH. Biostatical Analysis. $5^{\text {th }}$ ed. New Jersey: Pearson Education Inc.; 2010

11. US Food and Drug Administration, Department of Health and Human Services. Pharmaceutical Quality for the $21^{\text {st }}$ Century, A Risk-based Approach Progress Report. United States: Food and Drug Administration; 2007.

12. ICHQ8 (R2). Pharmaceutical Development; 2009. Available from: http:// www.ich.org/fileadmin/Public_Web_Site/ICH_Products/Guidelines/ Quality/Q1A R2/Step 4/Q1A_R2 Guideline.pdf $>$ (ICHonline)

13. ICH Q2 (R1). Validation of Analytical Procedures; 1994. Available from: http://www.ich.org/fileadmin/Public_Web_Site/ICH_Products/ Guidelines/Quality/Q1A R1/Step 4/Q1A_R1_Guideline. pdf $>$ (ICHonline)

14. ICH Q9 (R2). Quality Risk Management; 2005. Available from: http:// www.ich.org/fileadmin/Public Web_Site/ICH_Products/Guidelines/ Quality/Q1A_R2/Step 4/Q1A_R 2_Guideline.p̄p $>$ (ICHonline)

15. Ermer J, Miller JH, editors. Method Validation in Pharmaceutical Analysis: A Guide to Best Practice. Weinheim: Wiley-VCH Verlag $\mathrm{GmbH}$ and $\mathrm{Co}$. KGaA; 2005.

16. Schmidt AH, Molnár I. Using an innovative quality-by-design approach for development of a stability indicating UHPLC method for ebastine in the API and pharmaceutical formulations. J Pharm Biomed Anal 2013;78-79:65-74.

17. Ebrahimzadeh H, Asgharinezhad AA, Abedi H, Kamarei F. Optimization of carrier-mediated three-phase hollow fiber microextraction combined with HPLC-UV for determination of propylthiouracil in biological samples. Talanta 2011;85:1043-9.

18. Ebrahimzadeh H, Shekari N, Saharkhiz Z, Asgharinezhad AA. Simultaneous determination of chloropheniramine maleate and dextromethorphan hydrobromide in plasma sample by hollow fiber liquid phase microextraction and high performance liquid chromatography with the aid of chemometrics. Talanta 2012;94:77-83.

19. Reddy GS, Kumar SA, Debnath M, Kumar VR. Analytical method development and validation for simultaneous determination of dutasteride and tamsulosin in bulk as well as in pharmaceutical dosage form by using RP-HPLC. Int J Pharm Pharm Sci 2014;6:77-84.

20. Patel MM, Patel HD. Development and validation of RP-HPLC method for simultaneous estimation of terbinafine hydrochloride and mometasone furoate in combined dosage form. Int J Pharm Pharm Sci 2014;6:106-9.

21. Ahmad S, Rageeb M. Analytical method development and validation for the simultaneous estimation of emtricitabine and tenofovir by reversed-phase high performance liquid chromatography in bulk and table t dosage forms. Asian J Pharm Clin Res 2017;10:59-64. 